BOOK REVIEW

\title{
Child Soldiers and the Defence of Duress under International Criminal Law, by
}

Windell Nortje and Noëlle Quénivet, Palgrave Macmillan, 2019, 160 pp, £54.99, ISBN 978-3-030-20662-8

Atrocities committed by children are frequently explained away by arguments of coercion: children are forced by commanders to participate in acts of extreme violence, threatened with brutal punishment if they fail to comply. Indeed, in the limited cases where children or former child soldiers have come before courts, duress has often been raised as a key defence. In my own research on child perpetrators of genocide in Rwanda, ${ }^{1}$ 'irresistible constraint', as it was worded in the Rwandan legislation, was frequently invoked by defendants; in the very first juvenile case before the Rwandan courts, the 16-year-old defendant argued that he had been forced to kill his four nephews to save his own life. His plea was accepted in part - as a mitigating factor rather than complete defence. Duress was one of the defences raised by Dominic Ongwen before the International Criminal Court. Whilst being prosecuted for crimes committed as an adult, Ongwen had been forcibly conscripted into the Lord's Resistance Army in Uganda around the age of 9 or $10^{2}$ And duress has played in important role in refugee exclusion proceedings, with child soldiers arguing that they were coerced into committing crimes when seeking to negate individual criminal responsibility as a ground for exclusion. ${ }^{3}$

Much of the legal literature (itself quite limited) that addresses children's involvement in international crimes references duress as the most likely (or in Matthew Happold's words 'immediately relevant' $)^{4}$ defence, of which child soldiers might avail themselves. Yet, as Nortje and Quénivet correctly indicate, there is scant detailed examination in the literature of how the defence of duress applies, or might apply, to child soldiers in the trial context. Nortje and Quénivet's comprehensive work addresses this gap. Over the course of four substantive chapters, this book explores in detail how the various elements of the defence of duress might apply to children who have committed international crimes in the context of conflict and, thus, whether it would be open to such children to rely on duress for an acquittal. Their conclusion is that it would not: the application of the legal requirements of duress as currently interpreted as a justificatory defence would not exonerate such children. The authors thus make the argument for a 'child soldier-friendly' interpretation of duress as defined in Article 31(1)(d) of the Rome Statute, with the recasting of duress as an excusatory defence that takes account of the individual and societal circumstances of child soldiers whilst permitting the condemnation of the act.

The first substantive chapter of the book provides a useful contextualisation of duress in international criminal law. The authors justify their reliance on the definition in Article 31 (1)(d) of the Rome Statute (despite the jurisdictional bar in Article 26 on prosecuting those under 18 at the time of the alleged offence) on the basis that Article 31 codifies or crystallises the grounds for excluding criminal responsibility in international law. As such, they

\footnotetext{
1Jastine C Barrett, Child Perpetrators on Trial: Insights from Post-Genocide Rwanda (Cambridge University Press 2019).

${ }^{2}$ The judgment in this case was delivered on 4 February 2021: see https://www.icc-cpi.int/uganda/ongwen.

3 Joseph Rikhof, 'Child Soldiers and Asylum - Duality or Dilemma' in Mark Drumbl and Jastine C Barrett, Research Handbook on Child Soldiers (Edward Elgar Publishing, 2019) 390.

${ }^{4}$ Matthew Happold, Child Soldiers in International Law (Manchester University Press 2005) 154.
} 
argue that it is likely to 'fashion the way the defence will be understood and interpreted at the national level (or by any other potential ad hoc court or tribunal established with the purpose of prosecuting crimes committed on a specific territory)' (34-35). The authors conclude that the wording of Article 31, whilst suggesting that duress could be used as a full defence for all crimes (including killings), appears to approach duress as a justificatory defence by requiring the actor to conduct a 'lesser evil' or proportionality test. In effect then, its application to cases involving killings is likely to be limited (to, for example, cases where multiple killings are averted by the death of a few individuals).

In chapter 3, Nortje and Quénivet map out the specific elements of the defence of duress as contained in Article 31(1)(d) and seek to apply them to child perpetrators of international crimes. They conclude that child soldiers (and indeed any alleged perpetrators) would not be successful in invoking duress as it is currently defined and interpreted. This is partly due to duress being considered a justification rather than an excuse and thus a greater focus being placed on the act committed as opposed to the actor. The authors assert that a more nuanced understanding of perpetrators and the circumstances in which they act is needed. This chapter presents some interesting perspectives on the concrete application of the elements of duress to the specific circumstances of the child soldier. Nortje and Quénivet argue that children are often subject to an 'omnipresent' threat, living with an internalised and constant fear of physical or psychological harm (56): there will often be no actual contemporaneous threat of physical harm that is operating on the mind of the child when he or she is committing the act. As such, the requirement for immediacy and a direct link between the threat and the act would not be met. The authors suggest that this element would more likely be met if the child committed a crime soon after recruitment, as children are often threatened with death during this time if they refuse to fight or are required to commit atrocities as part of their initiation. Nortje and Quénivet also argue that it would be difficult for most child soldiers to show intention to avert the threat. Whilst the authors acknowledge that some children do exercise agency and would have capacity to resist an unlawful order, they contend that the majority would not. Child soldiers' moral values may have become distorted through prolonged exposure to the armed group, in some cases becoming acculturated to violence. Even if a child soldier is capable of understanding the immoral or unlawful nature of an act, they often lack the physical and mental capacity to challenge it.

The limitations of and exclusions from the defence of duress are the focus of chapter 4. Nortje and Quénivet outline the legal obligation on soldiers to assume a higher level of accepted risk that has developed through case law and argue that its application to child soldiers appears inappropriate. Child soldiers, both in state-armed forces and armed opposition groups, are unlikely to be considered 'trained' soldiers and are also unlikely to have the same capacity as an adult to assume danger. The authors then address the 'prior fault' doctrine, pursuant to which an individual must show that they did not voluntarily place themselves in the situation that led to the duress (such as joining an armed group that is known for committing atrocities). Whilst accepting that some children may voluntarily enrol, the authors propound that this should not automatically result in a rejection of a plea of duress: child soldiers may enrol for a variety of reasons (and, in some instances, the enrolment cannot be considered genuinely voluntary); they may not be fully cognisant of the crimes committed by the group; where time has passed between recruitment and commission of an offence, a child's moral understanding may have changed; and/or they may have attempted to escape the group. Where a child has been forcibly recruited into a group, a defence of duress should be easier to rely on, although this would be more difficult where a child does not attempt to escape the group and embraces its ideology. The authors thus make 
the argument for a reversal of the burden of proof in respect of these two elements: a rebuttable assumption that child soldiers do not have a special duty to assume danger, and a rebuttable assumption that they do not 'voluntarily' join armed groups or, where they do, that they were unaware of the scale of atrocities committed and/or could not escape.

In chapter 5, the authors explore duress from the perspective of an excuse rather than justification and argue that this would be a more appropriate framing. With a focus on the culpability of the actor as opposed to the character of the conduct, a claim of excuse would acknowledge the unlawfulness of the act committed, confirming society's condemnation of the act, whilst also taking account of the overall context in which the crimes were committed and the perpetrator's previous experience as well as free will (or lack thereof) (115). The authors draw the reader's attention to the fact that some child soldiers embrace the armed conflict environment and are not 'victims' of bad surroundings: as such, they argue that in any case involving a child soldier case, the individual's awareness of choices open to him or her should be analysed critically. Arguing in favour of duress as a full defence and thus applicable to all crimes including those leading to the death of an individual where the perpetrator resisted but committed the act to save a life or lives, Nortje and Quénivet advise the retention of a (revised) proportionality test that takes account of the autonomy of the individual in the circumstances, but the removal of the greater harm test. This, the authors argue, would enable a distinction to be made between those who embrace the ideology of the group and commit crimes to further themselves and those who commit crimes as they had no opportunity to avoid acting unlawfully.

Nortje and Quénivet present persuasive arguments in favour of recasting duress as an excuse rather than a justification - not only for child soldiers but for all perpetrators. This reframing would enable its use as a ground for excluding responsibility (including in murder cases) or as a mitigating factor, thus reflecting the whole spectrum of culpability. This approach is convincing if we are to recognise the fair trial rights of those accused of international crimes: the right to raise a defence that provides the prospect of acquittal as well as mitigation must surely be open to those accused even of the most heinous crimes. There are a couple of weaknesses in the book. On occasion, the language used is a little awkward or emotive (for example, the authors talk of people being 'hauled' before the International Criminal Court, and of crimes with which children are 'stained') and, in some instances, I would have liked to have seen more substantiation for statements made. For example, when talking of the tendency at the international level to perceive children as victims rather than perpetrators, the authors state that if this 'trend perdures on the international level, it is likely to seep into the national level to the effect that children are considered more as victims than perpetrators and so excused in their criminal behaviour' (114). They make a similar claim, as outlined earlier, with respect to interpretation of the defence of duress under Article 31. The interconnectivity of and flow between international and national ideas is highly complex, and the acceptance of international ideas at the domestic level may be especially difficult where tensions run high - for example where the alleged crimes are particularly serious and emotive. The authors clearly recognise the tensions that may be present in a post-conflict society, but their statement could perhaps have been qualified and brief reference made to the literature on the interplay between global and local ideas. A further issue that I felt perhaps deserved more attention was the counter-narrative to the abused and coerced child soldier. Whilst the book claims to support a more nuanced understanding of child soldiers, and indeed does present examples of young people who have committed international crimes and have risen through the ranks, my impression was that the authors were sometimes uncomfortable grappling with what they call the 'oxymoronic dyad' (147) epitomised by the child soldier. This discomfort is 
understandable, particularly given the dominant narrative of victimhood, but in my view, the book would have benefitted from a more detailed discussion of child perpetrators who are not coerced - and indeed sometimes seemingly act with zeal - and how this might fit with a reframing of duress. Overall, however, these weaknesses do not detract from the book making a solid and valuable contribution to the scholarship on child soldiers and international criminal law.

Jastine C Barrett

University of Kent at Canterbury, Canterbury, UK Q jastinebarrett@hotmail.co.uk

(C) 2021 Jastine C Barrett https://doi.org/10.1080/18918131.2021.1889778 